\title{
1. Women's entrepreneurship: discussing legal perspectives in light of individual and institutional drivers
}

\author{
Ulrike Fasbender and Yue S. Ang
}

\section{INTRODUCTION}

Among the first to identify entrepreneurship as a worthy field of study, Schumpeter (1934) described the entrepreneur as a person "whose function was to carry out new combinations of means of production" (Carland, Hoy, Boulton, \& Carland, 1984, p. 354), which has been highlighted as essential to a nation's economic development. Traditionally, entrepreneurship has been seen as a male phenomenon. It is therefore not surprising that even though "women are one of the fastest rising populations of entrepreneurs, and contribute significantly to innovation, job creation and economies around the world," research on women's entrepreneurship is comparatively understudied (Brush, 2009, p. 612). This chapter is therefore dedicated to women's entrepreneurship. In particular, we aim at providing an interdisciplinary approach by discussing legal perspectives in light of individual and institutional drivers for women to become entrepreneurs.

The chapter is organized along four main sections. In the first section, we conceptualize entrepreneurship, introduce its process and its different forms - particularly, we explain intrapreneurship and differentiate commercial from social entrepreneurship. In the second section, we introduce the role of women in entrepreneurship. Specifically, we outline the historical roots of women's entrepreneurship and highlight the individual and institutional drivers which encourage them to become entrepreneurs. In the third section, we introduce different legal forms of UK enterprises (linked to the launch phase of the entrepreneurial process) in relation to the entrepreneurial intention and the drivers of women's entrepreneurship. Finally, in the fourth section, we outline legal forms as a platform of entrepreneurship and discuss the potential barriers that limit women's choice of legal forms. We then end with concluding thoughts.

\section{CONCEPTUALIZATION OF ENTREPRENEURSHIP}

Entrepreneurship can be conceptualized using a behavioral definition; in essence, creating a new venture (Gartner, 1989). An often used behavioral definition of entrepreneurship entails independent ownership and active management (or the expressed intention to do so) as elementary aspects of the entrepreneur (Carland et al., 1984; Stewart \& Roth, 2001; Rauch \& Frese, 2007b). However, in contrast to small business owners or general manag- 
ers, the entrepreneur is characterized by growth orientation and innovative behavior along with strategic management practices (Carland et al., 1984; Stewart Jr., Watson, Carland, \& Carland, 1999). Moreover, entrepreneurship entails specific task descriptions, such as the identification, evaluation, and exploitation of profitable opportunities (Shane \& Venkataraman, 2000). In the following, we introduce the process of entrepreneurship and its different forms - particularly, we explain intrapreneurship and differentiate commercial from social entrepreneurship.

\section{Process of Entrepreneurship}

According to Baron and Henry (2011), entrepreneurship is a continuing process that can be described along three major phases, the prelaunch phase, the launch phase, and the postlaunch phase as can be seen in Figure 1.1.

To begin with, the prelaunch phase includes the recognition and evaluation of profitable opportunities, the heart of every entrepreneurial activity. Moreover, among the entrepreneurial input activities are assembling initial resources and the accumulation of information for start-up. The success of entrepreneurial outcomes in this phase may be measured along the number and type of recognized opportunities, the amount of capital raised, or network-related factors, such as high-quality business partners or employees attracted. A successful prelaunch phase ideally leads to the actual launch
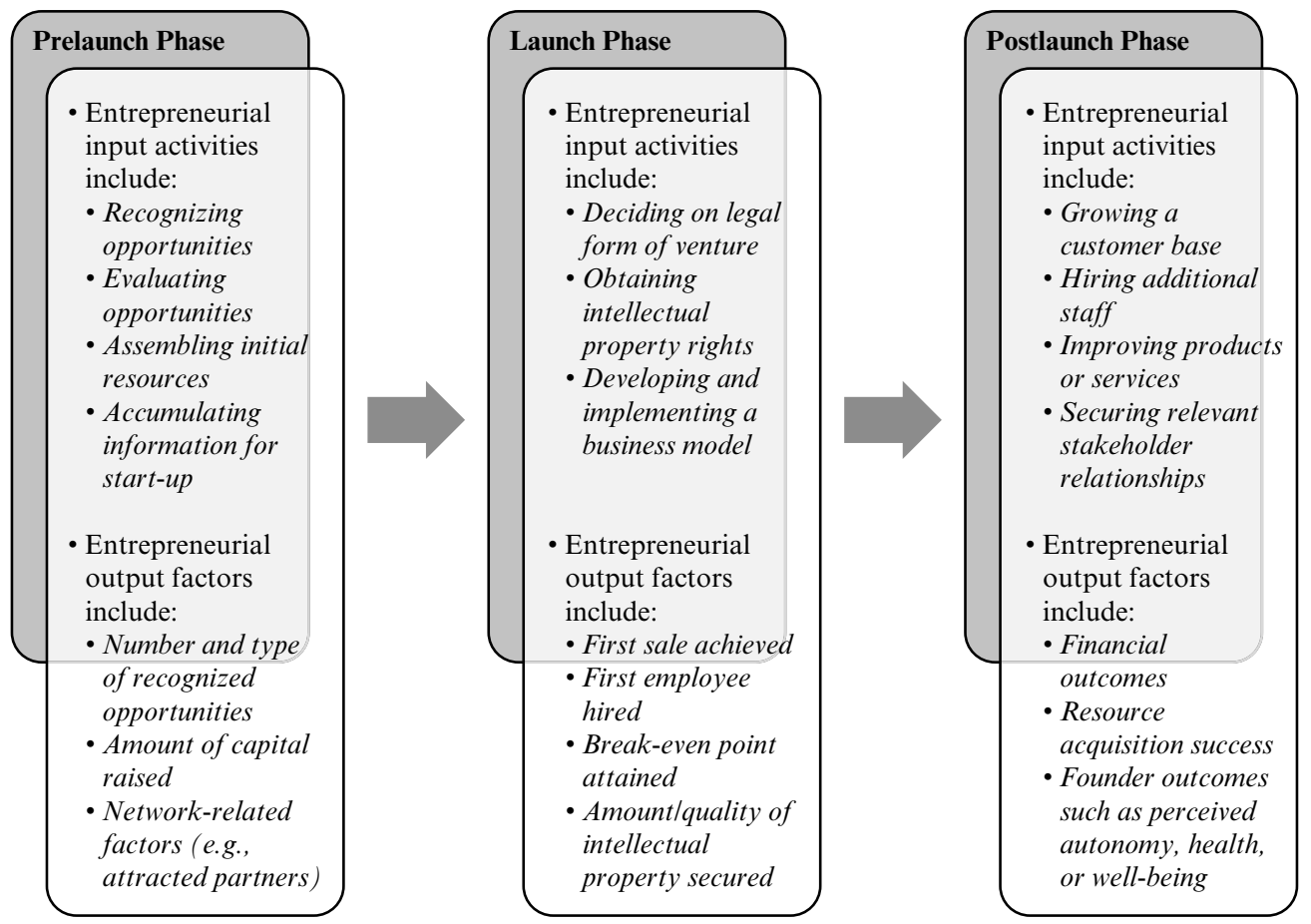

Figure 1.1 The entrepreneurial process, its input activities and output factors adapted from Baron and Henry (2011) 
of the new venture, where the legal form of the venture is chosen, intellectual property or financial resources may be secured, and a business model is developed and about to be implemented. The success of the launch phase may be measured by the time until first sale made, first employee hired, or break-even point achieved and the amount or quality of the intellectual property secured. After the new venture has been launched, entrepreneurial activities encompass growing a customer base, hiring additional staff, improving products or services, and further securing relevant stakeholder relationships by negotiating with others, influencing or motivating them. Finally, the success of the postlaunch phase may be measured along financial outcomes, acquisition of resources required, and individual outcomes, such as entrepreneurs' perceived autonomy, personal satisfaction, as well as their health and well-being. Baron and Henry's process model (2011) provides a good structure and overview of sample activities during the three phases of the entrepreneurial process; yet, it rather oversimplifies the complexity in which new venture creation takes place.

In fact, each of the phases is influenced by many different variables that can be classified as individual, interpersonal, and societal variables (Baron \& Henry, 2011). On the micro level, individual variables are the characteristics of entrepreneurs, including their cognitions, skills, knowledge, and personality (Baum \& Locke, 2004). On the meso level, interpersonal variables describe entrepreneurs' social capital, which refers to their social networks (i.e., acquaintances, colleagues, friends, and family members) as informal business channels that enable them greater access to information and entrepreneurial opportunities. Network size, diversity, and strengths have been identified as relevant network characteristics for entrepreneurs (Semrau \& Werner, 2014). On the macro level, societal variables are based on the ever-growing environmental dynamism of the twenty-first century that is driven by the overall economic situation, government policies, and industry-related factors, such as technological advancement and competitors' business strategies (Patzelt, Shepherd, Deeds, \& Bradley, 2008; Baron \& Henry, 2011). The investigation of the individual, interpersonal, and societal variables as well as their complex interplay is of great interest for the understanding of the entrepreneurial process, which may help to explain why some new ventures are successful and others are not (Hitt, Beamish, Jackson, \& Mathieu, 2007; Hmieleski \& Baron, 2009).

\section{Different Forms of Entrepreneurship}

Although entrepreneurship is usually associated with the creation of a new venture, recognizing entrepreneurial opportunities for the development of new products or services can also occur within existing organizations (Lumpkin, 2007). In fact, even wellestablished companies embrace innovation and entrepreneurial behavior; they actively encourage employees by introducing entrepreneurial programs or creating an environment in which employees recognize and exploit such entrepreneurial opportunities within their organization, thus becoming so-called intrapreneurs (Kuemmerle, 2006; Lumpkin, 2007; Baron \& Henry, 2011). Companies such as 3M, Intel, or Google are well known for their activities and efforts in this respect (Deeb, 2016). Intrapreneurship can therefore be understood as the organizational counterpart of entrepreneurship taking into account the structural boundaries of an existing organization. 
In addition, even though Schumpeter (1934) had introduced entrepreneurship as a profit-oriented creation of a new venture (i.e., commercial entrepreneurship), social entrepreneurship - entrepreneurial activity with a social purpose - has received increasing attention in both theory and practice over the last decades (Austin, Stevenson, \& Wei-Skillern, 2006; Datta \& Gailey, 2012). Narrow definitions of social entrepreneurship describe the phenomenon as entrepreneurial activity that is using innovative approaches based on marked-related skills and business expertise to generate income for nonprofit organizations (Reis, 1999; Thompson, 2002). Yet, broader definitions refer to social entrepreneurship as entrepreneurial activity with a social purpose that can be set up as an either for profit or not for profit organization or even a hybrid of both combining social and commercial interests (Austin et al., 2006). Social entrepreneurship (either for or not for profit) has been highlighted in particular in the light of women's entrepreneurial effort and contribution to the informal economy (Datta \& Gailey, 2012; Haugh \& Talwar, 2016; Lortie, Castrogiovanni, \& Cox, 2017).

\section{WOMEN AND ENTREPRENEURSHIP}

In this section, we introduce the role of women in entrepreneurship. Specifically, we give an account of the historical roots of women and entrepreneurship, and highlight the drivers which motivate them to engage in entrepreneurship.

\section{Historical Roots of Women and Entrepreneurship}

Although research on mainstream entrepreneurship emerged in the 1930s (starting with Schumpeter, 1934), women's entrepreneurship is a fairly recent research phenomenon. Initial research has investigated entrepreneurship from a mainly male-focused perspective in a male-oriented business world, where women were seen as sole proprietorship firms or small "lifestyle" businesses (Baker, Aldrich, \& Nina, 1997; Yadav \& Unni, 2016). As can be seen in Figure 1.2, the emergence of research on women's entrepreneurship goes back to the late 1970s (Jennings \& Brush, 2013). Yet, for a long time, researchers have treated entrepreneurship as a rather gender-neutral phenomenon, where male and female entrepreneurs were assumed to be the same and hence, gender was not further

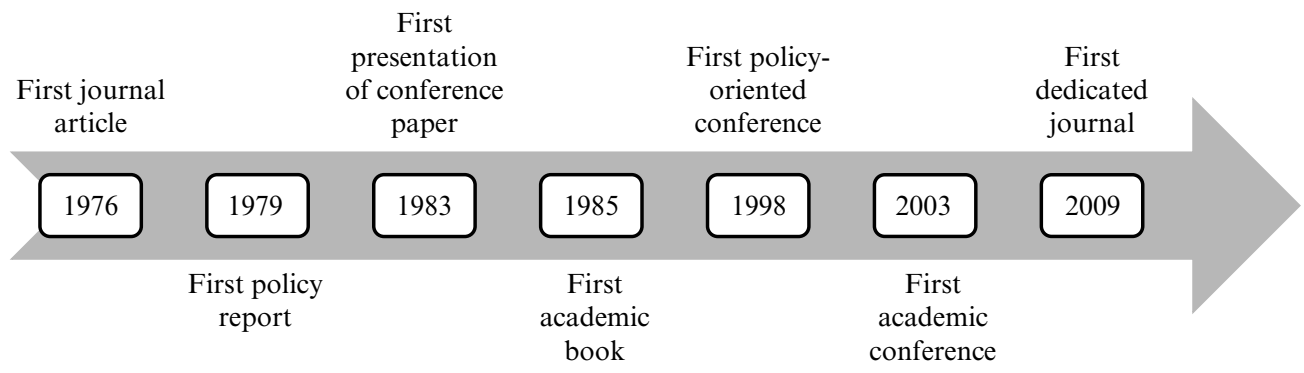

Figure 1.2 Timeline of research events related to women's entrepreneurship based on the chronological summary of Yadav and Unni (2016) 
distinguished or explored (Baker et al., 1997; Bruni, Gherardi, \& Poggio, 2004). As a result, research on the sub-domain of women's entrepreneurship did not significantly develop until the late 1990s with the first policy-oriented conference on women entrepreneurship and the first academic conference just a few years later (Jennings \& Brush, 2013).

In their chronological summary of studies on women entrepreneurship, Yadav and Unni (2016) refer to Eleanor Brantley Schwartz as the author of the first journal article on "Entrepreneurship: A new female frontier" in the Journal of Contemporary Business (1976), and the first policy report focusing on the unequal enterprise in the United States (1976). This was followed by the first conference paper on women entrepreneurship presented at the Babson College Conference on Entrepreneurship in 1983. Just two years later, the first academic book entitled Women in Charge: The Experiences of Female Entrepreneurs was published in the United Kingdom, indicating that research on women's entrepreneurship had become an increasingly international research phenomenon. In 1998, the first policy-oriented conference by the Organisation for Economic Co-operation and Development (OECD) on "Women entrepreneurs in SMEs: A major force in innovation and job creation" was held. This was followed by the first academic conference five years later. In 2009, the first dedicated academic journal entitled International Journal of Gender and Entrepreneurship was established. More recently, a range of review articles have been published, summarizing the current state of the art on women's entrepreneurship (e.g., Sullivan \& Meek, 2012; Henry, Foss, \& Ahl, 2016; Yadav \& Unni, 2016).

\section{Individual and Institutional Drivers of Women's Entrepreneurship}

Among the drivers underpinning women in taking up entrepreneurship are: (1) institutional gender ideology, as well as women's (2) individual motivation, and their (3) personality and individual differences.

\section{Institutional gender ideology}

Gender ideology describes the characteristic ideals constructed by society (Hechavarria \& Ingram, 2016). These social constructions can also be institutional in either masculine or feminine ideology. Individual behavior can be affected or molded by the forms of institution gender ideology. Further, there is an entrepreneurial gender divide between the ideology of hegemonic masculinity and emphasized femininity (Hechavarria \& Ingram, 2016). The former is the dominant norm and the latter is its alternative. Hegemonic masculinity identifies the ideals of male behavior; examples are "emotional self-control, competitive individualism, calculative rationality and heterosexuality" (Bretherton, 2003 cited in Hechavarria \& Ingram, 2016, p. 245). In other words, the dominant entrepreneurial qualities are to be alpha, hierarchical, being the risk-taker, independent, and invulnerable.

In contrast, femininity identifies traits which are found in "the loving nurturing mother and domestic home-maker," thus stressing the qualities of "social relations and togetherness" (Delph-Janiurek, 2000; Hoffman, 2001, cited in Hechavarria \& Ingram, 2016, p. 246). Therefore, emphasized femininity which is viewed as the alternative quality and that is meant to complement the dominant entrepreneurial qualities adopts collegiality, 
inclusivity, and risk-averseness, acknowledges women's vulnerability, and encourages shared responsibility (Choudhury, 2014; Ang, 2015).

Yet, the gender of being male or female is not the indicator for the entrepreneurial gender divide (Hechavarria \& Ingram, 2016). A woman can exhibit hegemonic masculinity ideology in her entrepreneurial profession just as well as a man can exhibit emphasized femininity ideology in his. The interesting point to make here is the institutional gender ideology affecting these individuals participating in them, for example, workers being unhappy or unfulfilled in employment (UK BIS, 2016). Commercial entrepreneurial activities can also emit hegemonic masculinity (Hechavarria \& Ingram, 2016). It is therefore likely that female entrepreneurs running commercial enterprises exhibit hegemonic masculinity.

In turn, social entrepreneurship "embodies the attributes of emphasized femininity" (Hechavarria \& Ingram, 2016, pp.247-248), suggesting that female entrepreneurs are more likely to align with the social organizational form than commercial organizational form. Interestingly, social organizational forms known as social enterprises thrive in the recession amongst struggling conglomerates (Esposito, 2013). This is an indication that emphasized femininity should therefore not be relegated as a component which complements the norm - rather its strong attributes should be acknowledged. In addition, a community which fosters emphasized femininity ideologies is likely to attract entrepreneurs running social enterprises (Hechavarria \& Ingram, 2016).

\section{Individual motivation}

The 2015 UK Department for Business Innovation and Skills (UK BIS, 2016) report indicates tipping points that drove individuals to entrepreneurship. The key motivating factors are (1) to have autonomy and flexibility, (2) to move away from unhappiness, uncertainty, or dissatisfaction with employment, and (3) for those who are unemployed, to generate an income. The report also indicates that most enterprises being set up because of necessity have turned out to be successful.

Moving away from formal employment for some women could be removing themselves from the institutional hegemonic masculine environment. Such masculine drivers as market dominance, rapid growth, high profits, excessive risk-taking, and perceived invulnerability may not complement their personalities. Entrepreneurship can be a solution to the challenges women are facing in jobs with traditional structures, such as unsuitable working conditions, limited career advancement opportunities, or conflicts arising between their work and private life. Previous research revealed that women who experienced conflict with their supervisors or thought they would do a better job than them, were more likely to become entrepreneurs (Zapalska, 1997). Also, entrepreneurship can be the breakthrough of the glass ceiling, which women often encounter within traditional organizational structures (Buttner \& Moore, 1997; Sullivan \& Meek, 2012). Further, because women often take greater responsibility for raising their children than men, entrepreneurship can be seen as a means toward more flexibility between their work and private life. Also, women have expressed a greater importance of family-related factors (in particular when having children) (DeMartino \& Barbato, 2003). However, the more time (male or female) entrepreneurs spend on child care activities, the more their self-employment duration decreases (Williams, 2004). Overall, empirical findings suggest that women are motivated to become entrepreneurs because of an anticipated gain in 
flexibility, which helps their career advancement and work-life balance (in particular higher family involvement) (Parasuraman \& Simmers, 2001; Malach-Pines \& Schwartz, 2008).

There are also good career reasons for women to become entrepreneurs, such as the need for financial success, innovation, roles, self-realization, recognition, and independence. While for men financial success and innovation matter most, women tend to value the need for independence and self-actualization highest when considering an entrepreneurial career (Maysami \& Goby, 1999; Carter, Gartner, Shaver, \& Gatewood, 2003). Yet, entrepreneurship is more than just the conducting of a business with a view to profit - it is also about innovating products and services alongside having a close connection with the community (Hobbs, 1997). The motivation to do good, connect with the community, and step outside the formal running of a business encourages some women to construct working conditions, career paths, and business objectives closer to their gender ideologies.

\section{Personality and individual differences}

Research on entrepreneurship has a tradition in investigating the entrepreneurial personality. Yet, some scholars argue that "a focus on the traits and personality characteristics of entrepreneurs will never lead us to a definition of the entrepreneur nor help us to understand the phenomenon of entrepreneurship" (Gartner, 1989, p. 48). In their conceptual model on entrepreneurs' personality characteristics and success, Rauch and Frese (2007a) revisit the personality approach on entrepreneurship and point out that personality traits need to be distinguished into proximal and distal individual differences. Broad personality traits capture the "big five," namely, extraversion, neuroticism, openness, agreeableness, and conscientiousness, whereas specific personality traits capture risk-taking, innovativeness, locus of control, and self-efficacy.

In general, men have been found to have higher entrepreneurial intentions than women (Crant, 1996; Zhao, Seibert, \& Hills, 2005). Further, a comprehensive twin study (based on 1285 pairs of identical twins and 849 pairs of same-sex fraternal twins) revealed that among the big five personality traits, extraversion and neuroticism have been found as important traits for women to become entrepreneurs, whereas for men only extraversion was found to be important (Zhang et al., 2009). With regard to the more specific personality traits, a meta-analysis based on 116 original studies $(N=26700$ individuals $)$ showed that independent of gender, innovativeness $(\rho=0.24)$, self-efficacy $(\rho=0.38)$, stress tolerance $(\rho=0.10)$, locus of control $(\rho=0.19)$, and risk-taking $(\rho=0.10)$ were positively associated with business creation (Rauch \& Frese, 2007b). Further, a proactive personality $(\rho=0.27$ ) has been found to be positively related to business success (Rauch $\&$ Frese, 2007b).

In addition to personality traits, work values may serve as proximal predictors of entrepreneurial intentions. For example, Hirschi and Fischer (2013) found that independent of gender, self-enhancement (i.e., salary and prestige), conservation (i.e., security and authority), and openness to changes (i.e., variety and autonomy) predicted students' entrepreneurial intentions. However, self-transcendence work values (i.e., altruism and benevolence) were more positively related to entrepreneurial intentions for women as compared to men. This result possibly reflects the earlier notion that women see "entrepreneurship not only as a means for self-enhancement but also as a possibility to 
contribute to the greater social good, as implied in models of social entrepreneurship" (Austin et al., 2006 cited in Hirschi \& Fisher, 2013, p. 226).

\section{LEGAL FORMS OF UK ENTERPRISES}

Discussing the legal forms of UK enterprises is linked to the launch phase of the entrepreneurial process. As the most proximal predictor of the actual launch, the entrepreneurial intention signals "how intensely [the entrepreneur] is prepared - and how much effort [he or she] is planning to commit - to carrying out entrepreneurial behavior" (Miranda, Chamorro-Mera, Rubio, \& Perez-Mayo, 2017, p. 69). Furthermore, the entrepreneurial intention can affect the choice of legal form. In the following, we thus introduce the different legal forms of UK enterprises and discuss them in light of the entrepreneurial intention and the drivers of women's entrepreneurship.

\section{Sole Trader}

A sole trader is a one-person business venture. It has an informal legal form giving traders full control over their business undertakings and records. On a micro level, the individual's entrepreneurial intention directly represents the sole trader's entrepreneurial intention (Feder \& Nitu-Antonie, 2017; Miranda et al., 2017). The sole trader's enterprise ceases as soon as the individual's entrepreneurial intention ends.

In relation to motivation, this legal form provides the entrepreneur with autonomy and flexibility. An entrepreneur with caring responsibilities could utilize this legal form just as could an entrepreneur who is career-driven. The business plan and its respective undertakings can be designed to cater for any entrepreneur's motivational drivers. For example, mothers referred to as "mompreneurs" can create suitable working conditions for themselves (Ozurumba, 2013, p. 42); and career-driven women can advance in their profession by utilizing a non-conventional business structure.

On the meso and macro levels, the sole trader can choose whether to utilize his or her "social capital" to promote economic success, or promote social impact, or a blending of both (Dees \& Anderson, 2006; Esposito, 2013). A cautious feature of sole tradership is its unlimited liability, which is the non-demarcation of the trader's personal wealth from the enterprise's finances. This feature can deter some women from obtaining a loan or credit or from considering business growth (Carter, Shaw, Lam, \& Wilson, 2007). The access to money sustains an entrepreneurial intention (Cabrera \& Mauricio, 2017).

\section{Partnership}

A partnership is an informal legal structure formed under section 1 Partnership Act 1890. It is a joint venture between two or more entrepreneurs who have unlimited liability. Section 6 affirms that a partnership's joint venture requires a joint entrepreneurial intention which is a sharing of each partner's entrepreneurial intention (Bratman, 1999).

Therefore, unlike the sole tradership, the individual partner's entrepreneurial intention is different from the partnership's joint entrepreneurial intention. Partnership has a feature where the joint entrepreneurial intention is dependent on all partners' 
entrepreneurial participation. Section 19 suggests that each partner is jointly committed to the joint entrepreneurial intention. Being jointly committed means having the participation of all the partners in the partnership (Gilbert, 2014), and maintaining a joint entrepreneurial intention. Hence, when one of the partners ceases trading, or when a partner refuses to "jointly commit" to the joint entrepreneurial intention, the whole partnership under section 32 alongside with its joint entrepreneurial intention dissolves (Gilbert 2014, p. 195; Gilbert, 1992).

A partnership addresses all the points mentioned in the sole tradership discussion above, and it also adds more features to the entrepreneurship levels. On the micro level, a joint venture initiates the sharing of everyone's characteristics including abilities, cognition, skills, knowledge, and personality (Baum \& Locke, 2004). The joint entrepreneurial intention depends on the competencies of the partners' personalities in the areas of personal and relationship-based business and management, business venturing, and human resources management (Cabrera \& Maurcio, 2017). The combination of a partnership's entrepreneurial activities relates to the competencies of the partners' personalities.

In relation to personality and individual differences, a partnership's joint venture and joint entrepreneurial intention might affect the respective partner's autonomy. The partner's own entrepreneurial intention might be different from the joint venture. Nevertheless, the individual driver for flexibility is supported under section 6 which provides shared locus of control over the venture, which under section 10 also includes shared responsibility.

On the meso and macro levels, partners have the option to utilize their social capital to promote economic success, or promote social impact or a blending of both (Dees \& Anderson, 2006; Esposito, 2013).

\section{Limited Liability Partnership (LLP)}

An LLP addresses all the points mentioned in the partnership discussion above except for each partner having limited liability under section 1(1) of the Limited Liability Partnership Act 2000. Limited liability is a formal legal structure which creates a separate legal identity between the enterprise and its entrepreneurs. It has a clear demarcation between every entrepreneur's personal wealth and the LLP's finances. With limited liability, section 7 ensures the LLP continues even when one of the partners ceases trading, meaning that section 7 also demarcates the LLP's entrepreneurial intention from its partners'.

On a micro level and distinguishing from the above partnership legal form, limited liability meant that there is no joint entrepreneurial intention shared between the partners. This feature supports the entrepreneur's autonomy and flexibility in pursuit of motivational drivers including risk-taking, financial success, self-realization, self-actualization, and recognition. On a meso and macro level, section 3(1A) provides the LLP with legitimacy through a certificate of incorporation. Legitimacy is a formality which gives the LLP recognition from its investors and creditors (Lee, 2009; Esposito, 2013; Yockey, 2015). This kind of legitimacy is therefore lacking in a sole trader and partnership.

Section 4 adds a feature to the entrepreneur's intrapersonal level where its partners can include non-natural persons. In relation to non-natural persons, venture capital firms can become LLP partners. These firms are "companies that raise money from investors, 
invest and manage the monies as one fund, and then loan money from this fund to entrepreneurs with business plans with very high potential for returns" (Panopoulos, 2010, p. 560). Therefore, section 4 supports the motivation for "wealth-maximization, competitiveness, aggressiveness" (Hechaverria \& Ingram, 2016, p. 243) and aligns with an entrepreneur's drivers for risk-taking, enterprise growth, financial success, exploiting social networks for stability, and gaining independence from banks.

LLPs are designed to invigorate an entrepreneurship culture which targets entrepreneurs seeking "prestige and credibility" (Freedman, 2000, p. 333), thus supporting the drivers for self-actualization, self-worth, and success. Yet, the limited liability's attraction can potentially shift entrepreneurial risks away from the partners, which might occur at the expense of other values like responsible risk-taking (Freedman, 2000). In addition, the lack of investors' protection ought to be critiqued as it might affect the entrepreneur's social network (Hyytinen \& Takalo, 2005). Nevertheless, limited liability partners have the option whether to utilize their social capital to promote economic success, or promote social impact, or a blending of both (Dees \& Anderson, 2006; Esposito, 2013).

\section{Private Limited Company (Ltd.)}

An Ltd. is governed under the Companies Act 2006. The entrepreneur has limited liability, which makes the Ltd. a formal legal form. Its limited liability features are similar to the LLP discussed above with the exception that an Ltd.'s entrepreneurial intention will not cease unless the current entrepreneur(s) running it chooses to dissolve it. Nevertheless, the crucial separation of entrepreneurial intention between the entrepreneur and enterprise supports the entrepreneur's autonomy.

On the micro level, an entrepreneur under section 7 can choose whether to incorporate a company alone or with other entrepreneurs, and thus having this option aligns the entrepreneur closer to his or her drivers and personality. Choosing the enterprise's structure also supports an entrepreneur's autonomy. He or she has the option under section 5 whether to have a company limited either by shares or guarantee. Entrepreneur flexibility is supported in terms of having the choice either to invest money (shares), or tangible goods other than money, for example property (guarantee). Owing to the level of flexibility in relation to having the suitable enterprise structure, this legal form closely aligns the entrepreneur's motivation for recognition, financial success, and self-actualization with his or her entrepreneurial intention. The limited liability's legal structures of the various combinations above are thoroughly analyzed before the most applicable one is adopted.

On the meso and macro level, an Ltd. supports both drivers for "wealth-maximization, competitiveness, aggressiveness" and "altruism, compassion and caring" (Hechavarria \& Ingram, 2016, p. 243). Like an LLP, legitimacy is provided under section 15 with the issue of the certificate of incorporation giving the Ltd. the opportunity to raise capital. Investors' confidence is further supported by the provisions under Part 11 where investors who are minority members of the enterprise can claim against it if they incur financial harm. Part 30 also protects investors who are minority members of the enterprise from being subjected to unfair prejudice. Finally, Part 29 protects creditors trading with the enterprise from being defrauded. Parts 11, 29, and 30 support the drivers for expanding the entrepreneurs' social network. 
An Ltd.'s design is mainly to increase economic success. As there is nothing in the Companies Act 2006 to prevent an enterprise promoting social objectives, this legislation is flexible for entrepreneur(s) wishing to utilize their social capital to promote social impact, or a blending of social and economic objectives.

\section{Community Interest Company (CIC)}

A CIC is also a private limited liability company (Ltd.) with a formal legal form governed under the Companies (Audit, Investigation and Community Enterprise) Act 2004. A CIC's design is mainly to promote social impact benefiting the community. Its entrepreneurial intention under section 26 requires the inclusion of social objectives. Similar to the private limited company (Ltd.) discussed above, the CIC's entrepreneurial intention will not cease unless the current entrepreneur(s) running it chooses to dissolve it.

On the micro level, the CIC's features are similar to the Ltd. However, there is an additional restriction; the CIC only supports for-profit entrepreneurs choosing to pursue the motivation of self-transcendence work values and the recognition for doing good (Hirschi \& Fischer, 2013). Therefore, the individual's entrepreneurial intention must reflect this.

On the meso and macro level, there are additional legal mechanisms ensuring the CIC's social network is kept at a legal standard. The regulator, who is appointed under section 27, upholds the legal standard. For a CIC limited by guarantee, section 29 imposes an asset-lock where the CIC's assets in the form of property are strictly kept for the benefit of the community. For a CIC limited by shares, section 30 places a cap on profit distributions and interests which ensures that money and interests are reinvested into the CIC for the benefit of the community.

Section 32 mandates the CIC's entrepreneurial intention of promoting a social objective is incorporated into the legal document called the articles of association. As a result, the CIC would have to legally honor its social objective(s) alongside its commercial objectives even during times of financial hardship. Furthermore, a CIC under section 52 is not allowed to re-register or change its legal form to an Ltd. These legal features support the drivers of recognition for doing good, conservation of wealth for the greater good, and self-transcendence work values of entrepreneurs (Hirschi \& Fischer, 2013). However, these features might not support the entrepreneur's drivers for flexibility, independence, or even having a degree of autonomy.

\section{Choice of Legal Forms}

The legal forms of UK enterprises offer a tapestry from which an entrepreneur chooses the form aligning closest to his or her drivers and entrepreneurial intention. In the next section, we explore how women's entrepreneurship is potentially affected by these legal forms. Furthermore, we discover barriers that potentially prevent women from fully utilizing their choice of legal form. 


\section{LEGAL FORMS AS A PLATFORM OF ENTREPRENEURSHIP}

Legal forms provide women entrepreneurs with a platform from which they promote their entrepreneurial intentions and their drivers. The direct impact relates to women's choice over the form best suited to their needs. For example, start-up and pop-up ventures are transient operations to which an informal legal form might be suited. Formal legal forms are suited for ventures which are ready for growth or maturity. This kind of impact is in no way different from the effect on men's entrepreneurship.

We find that the direct impact is especially profound in relation to some women going through phases like pregnancy or motherhood. These women are allowed (with the exception of the CIC) to switch between legal forms, thus giving them flexibility while sustaining their independence. The option to switch between temporary and permanent entrepreneurial activity ensures these women's ventures have continuity. Even though the phases of pregnancy or motherhood may change these women's entrepreneurial activities and entrepreneurial intention, a suitable legal form adopted for each phase can sustain their ventures, and therefore sustain their independence.

\section{Barriers that Potentially Limit Women's Choice of Legal Forms}

For women who wish to change their entrepreneurial intention owing to pregnancy or motherhood, we find that the full utilization of the legal forms is being diminished by barriers in the following areas: (1) access to money, (2) business network, and (3) legal assistance. These barriers prevent women from adopting the most suitable legal form aligning closest to their current drivers and entrepreneurial intention. Barriers impact the entrepreneurial intention by dis-aligning the change in entrepreneurs' drivers with the current adopted legal form and, thus, making it ill-fitted for the purposes of their entrepreneurial intention and entrepreneurial activities.

\section{Access to money}

Access to money sustains the entrepreneurial intention (Cabrera \& Mauricio, 2017). Legislations designed to support and fund certain women's entrepreneurship can exclude other women from being funded (Ozurumba, 2013). For example, if the eligibility process only favors women of a certain economic status, such as unemployed or underemployed women (Ozurumba, 2013), it would exclude established women entrepreneurs from seeking financial support for either expanding their enterprises or helping them through pregnancy or motherhood. As a result, legislations designed to support some eligible women could disadvantage women with established enterprises potentially leading to the diminishing of their independence and the maintenance of their chosen legal form.

In the context of obtaining bank loans, we find that direct discrimination against women in general is absent. Yet, results of an empirical study by Carter et al. (2007) show that bank loan applications of male and female entrepreneurs are evaluated differently. While female applicants were more likely to be questioned about their comprehension, male applicants were more likely to be questioned about their integrity and capability. Hence, "gender plays a role in the credit decision-making process as loan officers evaluate male and female applicants not just on the merits of their individual case, but also on the basis of their perceptions of men and women that have been imbued by gender 
socialization processes" (Carter et al., 2007, p. 439). Yet, it remains unclear to what extent approving bank loans may be affected by pregnancy or motherhood.

A nuance of indirect discrimination law could pose a potential solution toward protecting women entrepreneurs, especially those going through pregnancy or motherhood (Panopoulos, 2010). Indirect discrimination generally happens when "an unjustified adverse impact is produced for a protected class of persons by an apparently class-neutral action" (Ellis cited in Panopoulos, 2010, p. 550). A limitation to indirect discrimination law is that it only applies "when the cause of the disparate treatment of two groups is readily identifiable" (Panopoulos, 2010, p. 570). Established women entrepreneurs do not fit this description because they are as capable as men. Going through pregnancy or motherhood only could cause financing disparities in relation to the earnings and maintenance between men and women (Panopoulos, 2010). This is due to women taking the greater responsibility for raising their children (Kittay, 1999; DeMartino \& Barbato, 2003; Fineman \& Grear, 2013; Mackenzie, Rogers, \& Dodds, 2014). The focus of financing disparities is the proposed nuance underpinning indirect discrimination law favoring women entrepreneurs. Without the adaptation of this nuance of law, women entrepreneurs, especially those going through pregnancy or motherhood, may experience barriers preventing access to money and thus diminishing their opportunity to either switch legal forms or maintain their current legal form.

\section{Business network}

We mentioned above the glass ceiling found in the traditional organizational structure and we observe that it has prevented a culture of mentorship and networking for women (Villiers, 2010). As a result, female entrepreneurs potentially struggle with lower financial or managerial skills (Panopoulos, 2010). Perhaps, women value building networks differently from men as they tend to favor relationships over networks because they perceive the latter yielding short-term benefits (Panopoulos, 2010). Moreover, they also separate their personal lives from their professional lives (Panopoulos, 2010). Again, these are linked to the institutionalized gender ideology. A lack of business networks disadvantages female entrepreneurs from sharing knowledge and skills. This barrier prevents women from having full choice over the legal forms and it also prevents them from being able to switch legal forms.

\section{Legal assistance}

In regard to women-led enterprises and legal assistance, we indicate above that women are more likely to align with the social organizational form than commercial organizational form. Entrepreneurship, in particular social entrepreneurship, is a relatively recent legal development (Esposito, 2013; Yockey, 2015; Ang, 2017). The role of lawyers in general is to "understand [the entrepreneur's] business as well as the context and regulatory framework in which the [entrepreneur] operates" (Plerhoples, 2013, p. 253). Furthermore, social entrepreneurs' drivers including recognition for doing good, conservation of wealth for the greater good, and self-transcendence work values are novel and unstructured legal issues (Hirschi \& Fischer, 2013; Plerhoples, 2013). Lawyers must bridge entrepreneurship and law which warrants an activity requiring a full range of legal planning tools fit for entrepreneurial purposes (Hobbs, 1997). The rule of law and mechanisms for delivering the interests of commercial and social entrepreneurs are 
under-developed (Plerhoples, 2013) to the point that the body of entrepreneurial law must catch up with its corporate law counterpart. Some US law schools have set up legal advice centers like law clinics and pro bono foundations staffed with law students who provide commercial and social entrepreneurs with adequate legal assistance (Plerhoples, 2013). Law schools in the UK have much to catch up. This poses a barrier preventing women entrepreneurs from obtaining adequate legal assistance and therefore diminishing the opportunity to align their drivers and entrepreneurial intention adequately with a suitable legal form.

\section{CONCLUDING THOUGHTS}

We dedicated this chapter to women's entrepreneurship. In particular, we aimed at providing an interdisciplinary approach by discussing legal perspectives in light of individual and institutional drivers for women to become entrepreneurs. By doing so, we traced the origin of entrepreneurship by showing how much it has developed from Schumpeter, who envisaged it as a tool for economic development, to the emergence of social entrepreneurship. Furthermore, we conceptualized entrepreneurship by describing independent ownership and active management as elementary aspects. Also, we highlighted that entrepreneurship entails specific task descriptions, such as the identification, evaluation, and exploitation of profitable opportunities. In addition, we described the entrepreneurial process along three phases, namely the prelaunch phase, the launch phase, and the postlaunch phase.

Further, we introduced the role of women as entrepreneurs by summarizing the historical roots and revealing the drivers that encourage women to become entrepreneurs. Predominantly, we focused on the institutional gender ideology in contrast to individual drivers, namely women's individual motivation, personality, and individual differences.

Taking an interdisciplinary approach, we then introduced the different legal forms governing UK enterprises in light of institutional and individual drivers. We showed that the legal forms provide ample flexibility for women to engage in entrepreneurship in pursuance of either a lifestyle business or a professional career. Also, we found that women can (except for the CIC) switch legal forms in aligning a best suited form with their changing entrepreneurial interests and activities. Yet we also uncovered barriers that potentially limit women's choice of legal forms in that they dis-align women's entrepreneurial intention from their entrepreneurial activities. In particular, we addressed how lack of access to money, business network, and legal assistance potentially restrict women's choice of legal form.

To sum up, women's entrepreneurship is a growing phenomenon worldwide with research trying to catch up. Discussing legal perspectives in light of individual and institutional drivers shows that men and women are equipped with the same legal forms as platforms of their entrepreneurship allowing them to align their individual drivers and entrepreneurial intentions. Yet, women's choice can be limited due to gender-specific barriers that restrict them from fully utilizing their choice of legal forms. This can hinder the alignment of women's individual drivers and their entrepreneurial intentions, which potentially undermines the role of women as entrepreneurs in general. 


\section{REFERENCES}

Ang, Y. S. (2015). Ethical outsourcing and the act of acting together. In T. I. Wolf, T. Issa, \& M. Theil (Eds.), Empowering Organizations through Corporate Social Responsibility (pp. 113-130). Pennsylvania: IGI Global.

Ang, Y. S. (2017). Partners in social entrepreneurship: A UK approach to buyer's risk externalities. International and Comparative Corporate Law Journal, 12(2), 2-35.

Austin, J., Stevenson, H., \& Wei-Skillern, J. (2006). Social and commercial entrepreneurship: Same, different, or both? Entrepreneurship: Theory and Practice, 30(1), 1-22.

Baker, T., Aldrich, H. E., \& Nina, L. (1997). Invisible entrepreneurs: The neglect of women business owners by mass media and scholarly journals in the USA. Entrepreneurship \& Regional Development, 9(3), 221-238.

Baron, R. A., \& Henry, R. A. (2011). Entrepreneurship: The genesis of organizations. In S. Zedeck (Ed.), APA Handbook of Industrial and Organizational Psychology, Vol. 1 (pp. 241-273). Washington, DC: APA.

Baum, R. J., \& Locke, E. A. (2004). The relationship of entrepreneurial traits, skill, and motivation to subsequent venture growth. Journal of Applied Psychology, 89(4), 587-598.

Bratman, M. E. (1999). Faces of Intention: Selected Essays on Intention and Agency. Cambridge: Cambridge University Press.

Bruni, A., Gherardi, S., \& Poggio, B. (2004). Gender and Entrepreneurship: An Ethno-Graphic Approach. New York: Routledge.

Brush, C. G. (2009). Women entrepreneurs: A research overview. In A. Basu, M. Casson, N. Wadeson, \& B. Yeung (Eds.), The Oxford Handbook of Entrepreneurship (pp. 611-628). Oxford: Oxford University Press.

Buttner, H. E., \& Moore, D. P. (1997). Women's organizational exodus to entrepreneurship: Selfreported motivations and correlates with success. Journal of Small Business Management, 35, $34-46$.

Cabrera, E. M., \& Mauricio, D. (2017). Factors affecting the success of women's entrepreneurship: A review of literature. International Journal of Gender and Entrepreneurship, 9(1), 31-65.

Carland, J. W., Hoy, F., Boulton, W. R., \& Carland, J. A. C. (1984). Differentiating entrepreneurs from small business owners: A conceptualization. Academy of Management Review, 9(2), 354-359.

Carter, N. C., Gartner, W. B., Shaver, K. G., \& Gatewood, E. J. (2003). The career reasons of nascent entrepreneurs. Journal of Business Venturing, 18(1), 13-39.

Carter, S., Shaw, E., Lam, W., \& Wilson, F. (2007). Gender, entrepreneurship, and bank lending: The criteria and processes used by bank loan officers in assessing applications. Entrepreneurship: Theory and Practice, 31(3), 427-445.

Choudhury, B. (2014). New rationales for women on boards. Oxford Journal of Legal Studies, $34(3), 511-542$.

Crant, M. J. (1996). The Proactive Personality Scale as a predictor of entrepreneurial intentions. Journal of Small Business Management, 34(3), 42-49.

Datta, P. B., \& Gailey, R. (2012). Empowering women through social entrepreneurship: Case study of a women's cooperative in India. Entrepreneurship: Theory and Practice, 36(3), 569-587.

Deeb, G. (2016). Big companies must embrace intrapreneurship to survive. Forbes, February 18. Retrieved from https://www.forbes.com/sites/georgedeeb/2016/02/18/big-companies-must-embr ace-intrapreneurship-to-survive/\#6d41ddfc48ab.

Dees, G., \& Anderson, B. (2006). Framing a theory of social entrepreneurship: Building two schools of practice and thought. In R. Mosher-Williams (Ed.), Research on Social Entrepreneurship: Understanding and Contributing to an Emerging Field (pp. 39-66). Washington, DC: Aspen Institute.

DeMartino, R., \& Barbato, R. (2003). Differences between women and men MBA entrepreneurs: Exploring family flexibility and wealth creation as career motivators. Journal of Business Venturing, 18(6), 815-832.

Esposito, R. T. (2013). The social enterprise revolution in corporate law: A primer on emerging 
corporate entities in Europe and the United States and the case for the benefit corporation. William \& Mary Business Law Review, 4(2), 639-714.

Feder, E.-S., \& Nitu-Antonie, R.-D. (2017). Connecting gender identity, entrepreneurial training, role models and intentions. International Journal of Gender and Entrepreneurship, 9(1), 87-108.

Fineman, M. A., \& Grear, A. (2013). Vulnerability: Reflections on a New Ethical Foundation for Law and Politics. Farnham: Ashgate.

Freedman, J. (2000). Limited liability: Large company theory and small firms. Modern Law Review, 63(3), 317-354.

Gartner, W. B. (1989). "Who is an entrepreneur?" Is the wrong question. Entrepreneurship: Theory and Practice, 12(2), 47-68.

Gilbert, M. (1992). On Social Facts. Princeton, NJ: Princeton University Press.

Gilbert, M. (2014). Joint Commitment: How We Make the Social World. Oxford: Oxford University Press.

Haugh, H. M., \& Talwar, A. (2016). Linking social entrepreneurship and social change: The mediating role of empowerment. Journal of Business Ethics, 133(4), 643-658.

Hechavarria, D. M., \& Ingram, A. E. (2016). The entrepreneurial gender divide: Hegemonic masculinity, emphasized femininity and organizational forms. International Journal of Gender and Entrepreneurship, 8(3), 242-281.

Henry, C., Foss, L., \& Ahl, H. (2016). Gender and entrepreneurship research: A review of methodological approaches. International Small Business Journal, 34(3), 217-241.

Hirschi, A., \& Fischer, S. (2013). Work values as predictors of entrepreneurial career intentions. Career Development International, 18(3), 216-231.

Hitt, M. A., Beamish, P. W., Jackson, S. E., \& Mathieu, J. E. (2007). Building theoretical and empirical bridges across levels: Multilevel research in management. Academy of Management Journal, 50(6), 1385-1399.

Hmieleski, K., \& Baron, R. (2009). Entrepreneurs' optimism and new venture performance: A social cognitive perspective. Academy of Management Journal, 52(3), 473-488.

Hobbs, S. H. (1997). Towards a theory of law and entrepreneurship. Capital University Law Review, 26, 241-299.

Hyytinen, A., \& Takalo, T. (2005). Corporate law and small business finance: Mandatory vs. enabling rules. European Business Organization Law Review, 6(3), 449-466.

Jennings, J. E., \& Brush, C. G. (2013). Research on women entrepreneurs: Challenges to (and from) the broader entrepreneurship literature? Academy of Management Annals, 7(1), 663-715.

Kittay, E. F. (1999). Love's Labor: Essays on Women, Equality, and Dependency. London: Routledge.

Kuemmerle, W. (2006). Innovation in large firms. In M. Casson, B. Yeung, A. Basu, \& N. Wadeson (Eds.), The Oxford Handbook of Entrepreneurship (pp. 311-330). Oxford: Oxford University Press.

Lee, R. (2009). The emergence of social enterprises in China: The quest for space and legitimacy. Tsinghua China Law Review, 2, 79-99.

Lortie, J., Castrogiovanni, G. J., \& Cox, K. C. (2017). Gender, social salience, and social performance: How women pursue and perform in social ventures. Entrepreneurship \& Regional Development, 29(1-2), 155-173.

Lumpkin, G. T. (2007). Intrapreneurship and innovation. In R. J. Baum, M. Frese, \& R. Baron (Eds.), The Psychology of Entrepreneurship (pp. 237-263). Mahwah, NJ: Lawrence Erlbaum Associates.

Mackenzie, C., Rogers, W., \& Dodds, S. (2014). Vulnerability: New Essays in Ethics and Feminist Philosophy. Oxford: Oxford University Press.

Malach-Pines, A., \& Schwartz, D. (2008). Now you see them, now you don't: Gender differences in entrepreneurship. Journal of Managerial Psychology, 23(7), 811-832.

Maysami, R. C., \& Goby, V. P. (1999). Female business owners in Singapore and elsewhere: A review of studies. Journal of Small Business Management, 37(2), 96-105.

Miranda, F., Chamorro-Mera, A., Rubio, S., \& Perez-Mayo, J. (2017). Academic entrepreneurial intention: The role of gender. International Journal of Gender and Entrepreneurship, 9(1), 66-86.

Ozurumba, P. (2013). Girl power: How female entrepreneurs can overcome barriers to successful business. Women's Rights Law Reporter, 34(1), 24-57. 
Panopoulos, A. G. (2010). Barriers to financing: Is European Union indirect discrimination law the answer for female entrepreneurs? Cardozo Journal of Law and Gender, 16(3), 549-572.

Parasuraman, S., \& Simmers, C. A. (2001). Type of employment, work-family conflict and wellbeing: A comparative study. Journal of Organizational Behavior, 22(5), 551-568.

Patzelt, H., Shepherd, D. A., Deeds, D., \& Bradley, S. W. (2008). Financial slack and venture managers' decisions to seek a new alliance. Journal of Business Venturing, 23(4), 465-481.

Plerhoples, A. E. (2013). Representing social enterprise. Clinical Law Review, 20, 215-266.

Rauch, A., \& Frese, M. (2007a). Born to be an entrepreneur? Revisiting the personality approach to entrepreneurship. In J. R. Baum, M. Frese, \& R. A. Baron (Eds.), The Psychology of Entrepreneurship (pp. 41-65). Mahwah, NJ: Lawrence Erlbaum Associates.

Rauch, A., \& Frese, M. (2007b). Let's put the person back into entrepreneurship research: A metaanalysis on the relationship between business owners' personality traits, business creation, and success. European Journal of Work and Organizational Psychology, 16(4), 353-385.

Reis, T. (1999). Unleashing the New Resources and Entrepreneurship for the Common Good: A Scan, Synthesis and Scenario for Action. Battle Creek, MI: W. K. Kellogg Foundation.

Schumpeter, J. A. (1934). The Theory of Economic Development. Cambridge, MA: Harvard University Press.

Semrau, T., \& Werner, A. (2014). How exactly do network relationships pay off? The effects of network size and relationship quality on access to start-up resources. Entrepreneurship: Theory and Practice, 38(3), 501-525.

Shane, S., \& Venkataraman, S. (2000). The promise of entrepreneurship as a field of research. Academy of Management Review, 25(1), 217-226.

Stewart Jr., W. H., \& Roth, P. L. (2001). Risk propensity differences between entrepreneurs and managers: A meta-analytic review. Journal of Applied Psychology, 86, 145-153.

Stewart Jr., W. H., Watson, W. E., Carland, J. C., \& Carland, J. W. (1999). A proclivity for entrepreneurship: A comparison of entrepreneurs, small business owners, and corporate managers. Journal of Business Venturing, 14(2), 189-214.

Sullivan, D. M., \& Meek, W. R. (2012). Gender and entrepreneurship: A review and process model. Journal of Managerial Psychology, 27(5), 428-458.

Thompson, J. L. (2002). The world of the social entrepreneur. International Journal of Public Sector Management, 15(5), 412-431.

UK Department for Business Innovation and Skills (UK BIS) (2016). Longitudinal Small Business Survey: SME with Employees. Retrieved from https://www.gov.uk/government/publications/ small-business-survey-2015-businesses-with-employees.

Villiers, C. (2010). Achieving gender balance in the boardroom: Is it time for legislative action in the UK? Legal Studies, 30(40), 533-557.

Williams, D. R. (2004). Effects of childcare activities on the duration of self-employment in Europe. Entrepreneurship: Theory and Practice, 28(5), 467-484.

Yadav, V., \& Unni, J. (2016). Women entrepreneurship: Research review and future directions. Journal of Global Entrepreneurship Research, 6(12), 1-18.

Yockey, J. W. (2015). Does social enterprise law matter? Alabama Law Review, 66(4), 767-824.

Zapalska, A. (1997). A profile of woman entrepreneurs and enterprises in Poland. Journal of Small Business Management, 35(4), 76-82.

Zhang, Z., Zyphur, M. J., Narayanan, J., Arvey, R. D., Chaturvedi, S., Avolio, B. J., . . Larsson, G. (2009). The genetic basis of entrepreneurship: Effects of gender and personality. Organizational Behavior and Human Decision Processes, 110(2), 93-107.

Zhao, H., Seibert, S. E., \& Hills, G. E. (2005). The mediating role of self-efficacy in the development of entrepreneurial intentions. Journal of Applied Psychology, 90(6), 1265-1272. 